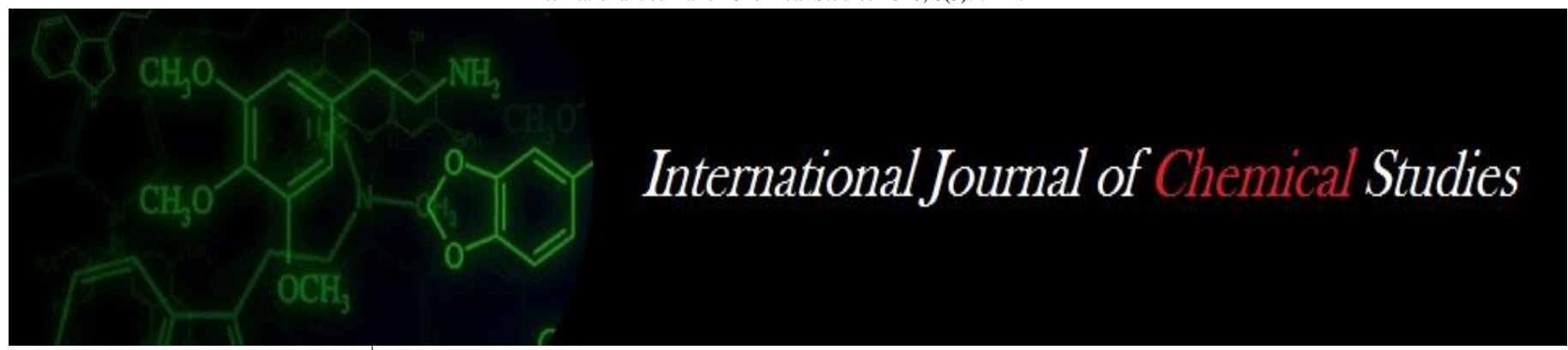

P-ISSN: 2349-8528

E-ISSN: 2321-4902

www.chemijournal.com

IJCS 2020; 8(3): 722-724

(C) 2020 IJCS

Received: 07-03-2020

Accepted: 09-04-2020

\section{SG Mahadevappa}

Associate Professor (Agro.),

Agricultural College, PJTSAU,

Palem, Nagarkurnool,

Telangana, India

\section{G. Sreenivas}

Principal Scientist (Agro.) and

Head, Agro Climate Research

Centre, PJTSAU,

Rajendranagar, Hyderabad,

Telangana, India

\section{Raji Reddy}

Director of Extension (Rtd.)

PJTSAU, Hyderabad,

Telangana, India

\section{A. Madhavi}

Principal Scientist, Soil Test

Crop Response scheme,

PJTSAU, Rajendranagar,

Hyderabad, Telangana, India

\section{S. S. Rao}

Principal Scientist,

Indian Institute of Millets

Research, Rajendranagar,

Hyderabad, Telangana, India

Corresponding Author:

SG Mahadevappa

Associate Professor (Agro.),

Agricultural College, PJTSAU,

Palem, Nagarkurnool,

Telangana, India

\section{Response of Bt cotton (Gossypium hirsutum L.) to varied nitrogen levels in Southern Telangana}

\author{
SG Mahadevappa, G Sreenivas, D Raji Reddy, A Madhavi and SS Rao
}

DOI: https://doi.org/10.22271/chemi.2020.v8.i3i.9289

\begin{abstract}
Field experiments were conducted during kharif 2014 and 2015 at Agricultural Research Institute, Rajendranagar to determine the optimum nitrogen level for Bt cotton in alfisols in Southern Telangana. Significantly more number of days $(31,47$ and 94) was taken to attain square initiation, flowering and boll development stage, respectively and higher drymatter production $\left(9.2,129,182\right.$ and $\left.239 \mathrm{~g} \mathrm{plant}^{-1}\right)$ was registered at square initiation stage, flowering, boll development and first picking stages, respectively with application of nitrogen at $225 \mathrm{~kg} \mathrm{ha}^{-1}$. Higher earliness index (0.78) was registered when no nitrogen applied over 150 and $225 \mathrm{~kg} \mathrm{ha}^{-1}$ with earliness index values of 0.75 and 0.74 , respectively. Significantly higher seed cotton yield $\left(1714 \mathrm{~kg} \mathrm{ha}^{-1}\right)$ was obtained with $225 \mathrm{~kg} \mathrm{~N} \mathrm{ha}^{-1}$ and was followed by $150 \mathrm{~kg} \mathrm{~N} \mathrm{ha}^{-1}\left(1704 \mathrm{~kg} \mathrm{ha}^{-1}\right)$. However, which were comparable with each other and significantly superior over no nitrogen and $75 \mathrm{~kg} \mathrm{~N} \mathrm{ha}^{-1}$ application. The rate of increase in seed cotton yield with application of 75, 150 and $225 \mathrm{~kg} \mathrm{ha}^{-1}$ over no nitrogen application was 54\%, 74\% and 75\%, respectively. It can be concluded that, higher seed cotton yield with higher B:C ratio can be obtained with application of nitrogen at $150 \mathrm{~kg} \mathrm{ha}^{-1}$ in Bt cotton in alfisols of South Telangana Zone.
\end{abstract}

Keywords: Cotton, nitrogen, phenology, seed cotton yield

\section{Introduction}

Cotton (Gossypium hirsutum L.), is one of the major cash crops of India, popularly known as 'White gold' and 'King of fibres' for its role in the national economy in terms of foreign exchange earnings and employment generation. In India, cotton cropping provides $60 \%$ of the fiber to textile industries, supplies more than one million metric ton of cooking oil, animal feed and 40 million metric tons of biomass in the form of cotton stalks. In India, cotton is grown in an area of 12.82 million ha with a production of 34.80 million bales and productivity of $462 \mathrm{~kg}$ lint ha-1, which is below the world's average of $790 \mathrm{~kg} \mathrm{ha}^{-1}$ during 2014-15. Telangana is a major cotton growing state cultivated in area of 1.71 million ha mostly under rainfed condition with a production of 3.80 million bales and productivity of the $377 \mathrm{~kg}$ lint ha ${ }^{-1}$ during 2014-15. Farmers are using eexcessive nitrogen fertilizers leading to heavy pest incidence in certain pockets whereas in some areas it is below optimum mainly because of the risk associated with the investment under uneven and erratic distribution of rainfall. For obtaining higher seed cotton yields water, nutrients and soils are essential resources, of which water and nitrogen are yield limiting factors.

Nitrogen deficiency in cotton reduces vegetative and reproductive growth and induces premature senescence, there by potentially reduces the yields (Tewiodle and Fernandez 1997) ${ }^{[14]}$, where as high nitrogen availability may shift the balance between vegetative and reproductive growth towards excessive vegetative development thus delaying maturity. Since nitrogen input is costly, judicious and efficient utilisation of nitrogen is essential for higher productivity of $\mathrm{Bt}$ cotton grown on alfisols under less rainfall receiving areas of South Telangana Zone. Keeping this in view, an experiment was formulated to study the effect of nitrogen levels on cotton production to optimize the nitrogen level for cotton.

\section{Materials and Methods}

The field experiment was carried out at Agricultural Research Institute, Professor Jayashankar Telangana State Agricultural University, Rajendranagar, Hyderabad during kharif seasons of 2014 and 2015 to determine the optimum nitrogen level for higher seed cotton yield. The experimental site was sandy loam in texture, neutral in reaction, low in available nitrogen, 
phosphorus and high in available potassium. The experiment executed with four nitrogen levels $\left(\mathrm{N}_{1}-0 \mathrm{~kg} \mathrm{ha}{ }^{-1}, \mathrm{~N}_{2}-75 \mathrm{~kg}\right.$ $\mathrm{ha}^{-1}, \mathrm{~N}_{3}-150 \mathrm{kgha}^{-1}$ and $\mathrm{N}_{4}-225 \mathrm{~kg} \mathrm{ha}^{-1}$ ) using cotton cultivar Mallika BG II sown at a spacing of $90 \mathrm{~cm} \mathrm{X} 60 \mathrm{~cm}$. A uniform dose of $60 \mathrm{~kg} \mathrm{ha}^{-1} \mathrm{P}_{2} \mathrm{O}_{5}$ as single super phosphate was applied to all the treatments as basal. Potassium @ $60 \mathrm{~kg}$ $\mathrm{ha}^{-1}$ as muriate of potash was applied in four equal splits along with nitrogen fertilizer as top dressing. Nitrogen was applied as per the treatments (wherever it was required) in the form of urea $(46 \% \mathrm{~N})$ in four equal splits $\left(1 / 4^{\text {th }}\right.$ each at 20,40 , 60 and 80 DAS). Observations on plant height, occurrence of phenophases, drymatter production, yield attributes and yield were recorded. Net monetary returns were worked out for different nitrogen levels. The data was analyzed statistically applying analysis of variance technique. The significance was tested by 'F' test (Snedecor and Cochron, 1967) ${ }^{[11]}$. Critical difference for examining treatment means for their significance was calculated at 5 per cent level of probability $(\mathrm{P}=0.05)$.

\section{Results and Discussions}

Incremental increase in nitrogen level resulted in significantly advances the days to attain different phenophases of cotton (Table 1). Significantly more number of days (31, 47 and 94) were taken to attain square initiation, flowering and boll development stage, respectively with $\mathrm{N}_{4}\left(225 \mathrm{~kg} \mathrm{ha}^{-1}\right)$ and followed by with $\mathrm{N}_{3}\left(150 \mathrm{~kg} \mathrm{ha}^{-1}\right)$ which were superior over $\mathrm{N}_{2}\left(75 \mathrm{~kg} \mathrm{ha}^{-1}\right)$ and $\mathrm{N}_{1}\left(0 \mathrm{~kg} \mathrm{ha}^{-1}\right)$. The average number of days were taken complete final picking of cotton was 142 days. Howard et al. (2001) ${ }^{[7]}$ observed similar results and concluded that higher doses of nitrogen lead to more vegetative growth and causes delay in maturity. The results were in conformity with the findings of Dong et al. (2012) ${ }^{[4]}$ and Munir et al. (2015) ${ }^{[9]}$.

Table 1: Effect of nitrogen levels on phenology and drymatter production of Bt cotton in alfisols (Pooled)

\begin{tabular}{|c|c|c|c|c|c|c|c|}
\hline \multirow{2}{*}{ Treatments } & \multicolumn{3}{|c|}{ No. of days to attain } & \multicolumn{4}{|c|}{ Drymatter $\left(\right.$ g plant $\left.^{-1}\right)$} \\
\hline & Square initiation & Flower ing & Boll development & Square initiation & Flower ing & Boll development & $1^{\text {st }}$ picking \\
\hline $\mathrm{N}_{1}-0 \mathrm{~kg} \mathrm{ha}^{-1}$ & 30 & 45 & 92 & 6.0 & 64 & 95 & 138 \\
\hline $\mathrm{N}_{2}-75 \mathrm{~kg} \mathrm{ha}^{-1}$ & 30 & 45 & 93 & 7.6 & 92 & 125 & 180 \\
\hline $\mathrm{N}_{3}-150 \mathrm{~kg} \mathrm{ha}^{-1}$ & 31 & 46 & 93 & 8.6 & 120 & 166 & 224 \\
\hline $\mathrm{N}_{4}-225 \mathrm{~kg} \mathrm{ha}^{-1}$ & 31 & 47 & 94 & 9.2 & 129 & 182 & 239 \\
\hline S. Em \pm & - & - & - & 0.42 & 3.3 & 5.6 & 5.6 \\
\hline $\mathrm{CD}(\mathrm{P}=0.05)$ & 0.5 & 0.9 & 0.48 & 1.25 & 9.7 & 16.6 & 16.5 \\
\hline
\end{tabular}

Graded levels of nitrogen significantly increased the drymatter production over lower levels of nitrogen at flowering, boll development and first picking stages. Analysis of the data showed that, significantly higher drymatter production $\left(9.2,129,182\right.$ and $\left.239 \mathrm{~g} \mathrm{plant}^{-1}\right)$ was registered with $\mathrm{N}_{4}\left(225 \mathrm{~kg} \mathrm{ha}^{-1}\right)$ at square initiation stage, flowering, boll development and first picking stages, respectively and was not differed significantly with $\mathrm{N}_{3}\left(150 \mathrm{~kg} \mathrm{ha}^{-1}\right)$ which recorded drymatter production of $8.6,120,166$ and $224 \mathrm{~g}$ plant $^{-1}$, respectively and drymatter production with $\mathrm{N}_{4}(225 \mathrm{~kg}$ $\left.\mathrm{ha}^{-1}\right)$ was significantly superior over $\mathrm{N}_{2}\left(75 \mathrm{~kg} \mathrm{ha}^{-1}\right)$ and $\mathrm{N}_{1}(0$ $\mathrm{kg} \mathrm{ha}^{-1}$ ). Higher drymatter production is an index of higher photosynthetic capacity of a plant. Relatively higher plant height, leaf area might be contributed by adequate supply of nitrogen with favorable effect on cell elongation leads more plant height, leaf area by enabling the plant to trap higher quantity of radiant energy leading to accumulation of higher photosynthates and dry matter in the plant. Enhanced drymatter production with adequate supply of nitrogen corroborates with the findings of Dadgale et al. (2014) ${ }^{[3]}$ and Sunitha et al. (2010) ${ }^{[13]}$.

Table 2: Effect of nitrogen levels on yield, nitrogen uptake and economics of Bt cotton in alfisols (Pooled)

\begin{tabular}{|c|c|c|c|c|c|c|}
\hline Treatments & No. of bolls plant & \\
\hline $\mathrm{N}_{1}-0 \mathrm{~kg} \mathrm{ha}^{-1}$ & 13 & Lint yield $\left(\mathbf{k g ~ h a}^{-1}\right)$ & Ginning (\%) & Earliness Index $^{\text {B:C Ratio }}$ & Seed cotton yield (kg ha-1) \\
\hline $\mathrm{N}_{2}-75 \mathrm{~kg} \mathrm{ha}^{-1}$ & 17 & 353 & 36.4 & 0.78 & 1.01 & 977 \\
\hline $\mathrm{N}_{3}-150 \mathrm{~kg} \mathrm{ha}^{-1}$ & 19 & 547 & 36.7 & 0.76 & 1.39 & 1506 \\
\hline $\mathrm{N}_{4}-225 \mathrm{~kg} \mathrm{ha}^{-1}$ & 19 & 630 & 37.1 & 0.75 & 1.45 & 1704 \\
\hline $\mathrm{S} . \mathrm{Em} \pm$ & 0.37 & 636 & 37.4 & 0.74 & 1.39 & 1714 \\
\hline $\mathrm{CD}(\mathrm{p}=0.05)$ & 1.1 & 19.2 & - & - & - & 57 \\
\hline
\end{tabular}

Significantly higher number of bolls plant ${ }^{-1}$ (19) was recorded with $\mathrm{N}_{4}\left(225 \mathrm{~kg} \mathrm{ha}^{-1}\right)$ and $\mathrm{N}_{3}\left(150 \mathrm{~kg} \mathrm{ha}^{-1}\right)$ over $\mathrm{N}_{2}\left(75 \mathrm{~kg} \mathrm{ha}^{-}\right.$ $\left.{ }^{1}\right)$ and $\mathrm{N}_{1}\left(0 \mathrm{~kg} \mathrm{ha}^{-1}\right)$ which recorded the lowest bolls plant ${ }^{-1}$ (13). Nitrogen acts as a source for higher retention of bolls and more number of bolls plant ${ }^{-1}$ at higher level of nitrogen application might be due to favourable effect on growth and translocation of photosynthates towards squares. Similar results were reported by Gundlur et al. (2013) ${ }^{[5]}$ and Hosamani et al. (2013) [6]. It was observed that, nitrogen levels had no significant influence on ginning percentage. Significantly higher earliness index $(0.78)$ was registered with $\mathrm{N}_{1}\left(0 \mathrm{~kg} \mathrm{ha}^{-1}\right)$ over $\mathrm{N}_{3}\left(150 \mathrm{~kg} \mathrm{ha}^{-1}\right)$ and $\mathrm{N}_{4}\left(225 \mathrm{~kg} \mathrm{ha}^{-1}\right)$ with earliness index values of 0.75 and 0.74 , respectively, but they were comparable with each other (Table 2). However, earliness index $(0.76)$ found with $\mathrm{N}_{2}\left(75 \mathrm{~kg} \mathrm{ha}^{-1}\right)$ was at par with other higher levels of nitrogen application. The favourable regime of increased nitrogen application in the soil might be resulted in prolonged vegetative phase leads to delayed maturity causes lower earliness index. Similar results were reported by Bandyopadhyay et al. (2009) ${ }^{[1]}$. Higher B:C ratio with $\mathrm{N}_{3}\left(150 \mathrm{~kg} \mathrm{ha}^{-1}\right)$ was might be due to higher seed cotton yield at that particular level of nitrogen application. These results were in conformity with the findings of Srinivasulu et al. (2006) ${ }^{[12]}$ and Pandagale et al. $(2015)^{[10]}$.

Significantly higher seed cotton yield (1714 $\left.\mathrm{kg} \mathrm{ha}^{-1}\right)$ was obtained with $\mathrm{N}_{4}\left(225 \mathrm{~kg} \mathrm{ha}^{-1}\right)$ and was followed by $\mathrm{N}_{3}(150$ $\mathrm{kg} \mathrm{ha}^{-1}$ ) with seed cotton yield of $1704 \mathrm{~kg} \mathrm{ha}^{-1}$. However, which were comparable with each other and significantly superior over $\mathrm{N}_{2}\left(75 \mathrm{~kg} \mathrm{ha}^{-1}\right)$ and $\mathrm{N}_{1}\left(0 \mathrm{~kg} \mathrm{ha}^{-1}\right)$. The rate of increase in seed cotton yield with $\mathrm{N}_{2}\left(75 \mathrm{~kg} \mathrm{ha}^{-1}\right), \mathrm{N}_{3}(150 \mathrm{~kg}$ $\left.\mathrm{ha}^{-1}\right)$ and $\mathrm{N}_{4}\left(225 \mathrm{~kg} \mathrm{ha}^{-1}\right)$ over $\mathrm{N}_{1}\left(0 \mathrm{~kg} \mathrm{ha}^{-1}\right)$ was $54 \%, 74 \%$ and $75 \%$, respectively. Similar results were observed with lint 
yield. The substantial increase in seed cotton yield due to application of higher levels of nitrogen might be due to favorable effect of nitrogen on growth attributes like plant height, increased number of bolls plant ${ }^{-1}$, drymatter accumulation plant ${ }^{-1}$ and its subsequent translocation towards sink improved the seed cotton yield. These results are in conformity with Dadgale et al. (2014) ${ }^{[3]}$. Similar positive response of nitrogen on seed cotton yield was observed by Basavanneppa (2005) ${ }^{[2]}$ and Meena et al. (2007) ${ }^{[8]}$.

\section{Conclusion}

It can be concluded that, higher seed cotton yield with higher $\mathrm{B}: \mathrm{C}$ ratio can be obtained with application of nitrogen at 150 $\mathrm{kg} \mathrm{ha}^{-1}$ in Bt cotton in alfisols of South Telangana Zone

\section{References}

1. Bandyopadhyay KK, Prakash AH, Sankaranarayanan K, Dharajothi B, Gopalakrishnan N. Effect of irrigation and nitrogen on soil water dynamics, productivity and inputuse efficiency of Bt cotton (Gossypium hirsutum) in a Vertic Ustropept. Indian Journal of Agricultural Sciences. 2009; 79(6):448-453.

2. Basavanneppa MA, Angadi VV, Biradar DP. Productivity and endotoxin expression as influenced by nutrient levels and nitrogen doses application in $B t$ cotton under irrigation. Journal of Cotton Research and Development. 2015; 29(1):39-44.

3. Dadgale PR, Chavan DA, Gudade BA, Jadhav SG, Deshmukh VA, Suresh Pal. Productivity and quality of Bt cotton (Gossypium hirsutum) as influenced by planting geometry and nitrogen levels under irrigated and rainfed conditions. Indian Journal of Agricultural Sciences. 2014; 84(9):1069-1072.

4. Dong H, Li W, Eneji AE, Zhang D. Nitrogen rate and plant density effects on yield and late season leaf senescence of cotton raised on a saline field. Field Crops Research. 2012; 126:137-144.

5. Gundlur SS, Rajkumara S, Neelakanth JK, Ashoka P, Khot AB. Water and nutrient requirement of $\mathrm{Bt}$ cotton under vertisols of Malaprabha command. Karnataka Journal of Agricultural Sciences. 2013; 26(3):368-371.

6. Hosamani V, Halepyati AS, Desai BK, Koppalkar BG, Ravi MV. Effect of macro nutrients and liquid fertilizers on the growth and yield of irrigated Bt cotton (Gossypium hirsutum L.). Karnataka J Agric. Sci. 2013; 26(2):200204.

7. Howard DD, Gwathmey CO, Essington ME, Roberts RK, Mullen MD. Nitrogen fertilization of no-till cotton on loess- derived soils. Agronomy Journal. 2001; 93:157163.

8. Meena RL, Babu VR, Nath A. Effect of fertilizer management on cotton under saline soils of Gujarat. Bharatiya Krishi Anusandhan Patrika. 2007; 22:206-210.

9. Munir MK, Tahir M, Saleem MF, Yaseen M. Growth, yield and earliness response of cotton to row spacing and nitrogen management. The Journal of Animal and Plant Sciences. 2015; 25(3):729-738.

10. Pandagale AD, Khargkharate VK, Kadam GL, Rathod SS. Response of Bt cotton (Gossypium hirsutum L.) to varied plant geometry and fertilizer levels under rainfed condition. Journal of Cotton Research and Development. 2015; 29(2):260-263.

11. Snedecor GW, Cochron WG. Statistical Methods. Oxford and IBH Publishing company 17, Parklane, Calcutta, 1967, 172-177.
12. Srinivasulu K, Hema K, Prasad NVVSD, Krishna Rao KV. Performance of cotton hybrids under different spacings and nitrogen levels in black cotton soils of coastal Andhra Pradesh. Journal of Cotton Research and Development. 2006; 20:99-101.

13. Sunitha V, Chandra Sekhar K, Veera Raghavaiah R. Performance of $\mathrm{Bt}$ cotton hybrids at different nitrogen levels. Journal of Cotton Research and Development 2010; 24(1):52-55.

14. Tewiodle Fernadez CJ. Vegetative and reproductive dry weight inhibition in nitrogen and phosphorus deficient Pima cotton. Indian Journal of Agronomy 1997; 38(4):609-612. 